\title{
Linking Customer Interaction and Innovation: The Mediating Role of New Organizational Practices
}

\author{
Nicolai J. Foss \\ Center for Strategic Management and Globalization, Copenhagen Business School, 2000 Frederiksberg, Denmark; and \\ Department of Strategy and Management, Norwegian School of Economics and Business Administration, \\ N-5045 Bergen, Norway, njf.smg@cbs.dk \\ Keld Laursen \\ DRUID, Department of Innovation and Organizational Economics, Copenhagen Business School, \\ 2000 Frederiksberg, Denmark, kl.ino@cbs.dk \\ Torben Pedersen \\ Center for Strategic Management and Globalization, Copenhagen Business School, \\ 2000 Frederiksberg, Denmark, tp.smg@cbs.dk
}

\begin{abstract}
$\mathrm{T}^{\mathrm{h}, \mathrm{sen}}$ notion that firms can improve their innovativeness by tapping users and customers for knowledge has become prominent in innovation studies. Similar arguments have been made in the marketing literature. We argue that neither literatures take sufficient account of firm organization. Specifically, firms that attempt to leverage user and customer knowledge in the context of innovation must design an internal organization appropriate to support it. This can be achieved in particular through the use of new organizational practices, notably, intensive vertical and lateral communication, rewarding employees for sharing and acquiring knowledge, and high levels of delegation of decision rights. In this paper, six hypotheses were developed and tested on a data set of 169 Danish firms drawn from a 2001 survey of the 1,000 largest firms in Denmark. A key result is that the link from customer knowledge to innovation is completely mediated by organizational practices.
\end{abstract}

Key words: interaction with customers; innovation; new organizational practices

History: Published online in Articles in Advance November 4, 2010.

\section{Introduction}

In terms of innovation performance, do firms gain from being orientated toward, perhaps even working directly with, their customers and other users of their products and services? And if so, what role do firms' organizational practices play in this process? A substantial body of research, built since the 1980s, would seem to confirm the first assumption but has not systematically addressed the role of organizational practices. Thus, the user innovation literature (Lilien et al. 2002, Neale and Corkindale 1998, Rosenberg 1982, Urban and von Hippel 1988) and substantial parts of the open innovation literature (Chesbrough 2003, Laursen and Salter 2006, Lichtenthaler 2008) ${ }^{1}$ argue that established firms can improve their innovation performance by working closely with users and customers in the innovation process. However, this literature says little about the role of firms' internal organization in this process. The marketing literature suggests that innovation may play a key role in the understanding of the link between market orientation (i.e., being oriented toward customers as well as competitors) and firm-level performance (Han et al. 1998, Hurley and Hult 1998, Lukas and Ferrell 2000, Slater and Narver 1994), and it suggests even that firms' success in linking market orientation to new product development and financial performance may depend on their internal organization. However, this work typically studies only isolated practices or considers such practices to be part of the market orientation construct (e.g., Slater and Narver 1994). Thus, it provides an incomplete account of how customer and user knowledge might be leveraged in the context of innovation. For example, although interfunctional coordination (Slater and Narver 1994) may increase the value and use of customer and user knowledge within the firm, it does not help to explain how the firm initially sources this knowledge; other organizational practices may be needed. In the following we address, theoretically and empirically, how firms' organizational practices influence their sourcing and use of external knowledge. There is some evidence to suggest that companies increasingly are changing their internal organization toward greater delegation of authority and better communication within the firm (particularly along the lateral dimension) and performance incentives (e.g., Zenger and Hesterly 1997). One of the effects of these organizational changes may be that firms are becoming better at accessing, exploiting, and leveraging customer knowledge in the context of innovation. Specifically, our line of argument is that under many circumstances customers will either have initiated 
an innovation that eventually is commercialized by an established firm (von Hippel 2005) or possess knowledge critical to an established firm for the introduction of a product innovation (Urban and von Hippel 1988). If the established firm has appropriate organizational practices for assimilating external innovations or knowledge, then successful commercialization will be more likely.

We would suggest, first, that greater delegation of decision rights increases the probability that external knowledge will be brought inside the boundaries of the firm; second, that intensive vertical and lateral communication enables the dissemination of this knowledge inside the firm; and third, that it is possible to incentivize employees such that knowledge will more likely be leveraged in the context of innovation. These "umbrella" organizational practices are often implemented via more specific organizational practices (e.g., extensive delegation of decision rights may involve broader job descriptions, projects, total quality management initiatives, etc.). A key point is that the relevant practices are complementary with respect to leveraging customer knowledge in the context of innovation. Based on our theoretical discussion, we can derive a set of related hypotheses. The empirical analysis draws on survey results from 169 Danish private firms; the survey was conducted in 2001 and included the 1,000 largest Danish manufacturing and service firms. Our overall finding is that there is no direct relation between customer involvement and innovation but that organizational practices provide a strong mediating effect.

The main contribution of this paper is to introduce the organizational dimension into the user innovation literature. This implies identifying important organizational aspects of absorptive capacity in the context of user innovation. On a related note, we extend the argument in the innovation literature (e.g., Laursen and Foss 2003, Love and Roper 2009) on the impact on innovation of complementary organizational practices beyond its focus on exploiting and combining internally held knowledge to include knowledge held by external parties. The literature on organizational complementarities suggests two approaches: the interaction approach and the systems approach (see Ennen and Richter 2010). In a regression analysis setting, the interaction approach (e.g., Capelli and Neumark 2001) examines the effect of a few organizational practices, typically two by two. In contrast, the systems approach (e.g., Ichniowski et al. 1997, Laursen and Foss 2003) looks at the relative performance outcomes of entire sets of variables, also in a regression analysis. Our approach is akin to the systems approach. However, the systems approach involves the lumping together of a set of distinct organizational practices without specifying any causal relationships between them. We suggest the use of structural equation modeling (LISREL) to help overcome this problem because it allows for a deeper causal structure running from broadband interaction with customers over delegation, to knowledge incentives and internal communication, and finally to higher innovation performance.

\section{Customers, Innovation, and New Organizational Practices}

\section{Context: The Role of Users and Customers in Product Innovation}

The ability of firms to innovate is a central component in the processes of gaining and sustaining competitive advantage (Dierickx and Cool 1989, McEvily and Chakravarthy 2002, Nelson and Winter 1982, Teece et al. 1997, Zott 2003). Empirical studies demonstrate that innovative firms show higher profits, higher market value, better credit ratings, higher market share, and higher probabilities of survival in the market (Banbury and Mitchell 1995, Blundell et al. 1999, Cefis and Marsili 2005, Czarnitzki and Kraft 2004, Geroski et al. 1993, Hall 2000). To capture the benefits of being innovative, firms increasingly attempt to improve their innovation capacity by tapping into sources of external knowledge (Chesbrough 2003, Fey and Birkinshaw 2005, Laursen and Salter 2006, Lichtenthaler 2008).

It has long been recognized that interaction with customers (and users who may not be customers) can be a crucial antecedent to innovation (Freeman 1968, Linder 1961, Rosenberg 1982, von Hippel 1976). von Hippel (1976) documents the importance of the phenomenon and shows that more than $80 \%$ of innovations in the scientific instruments industry were invented, prototyped, and first field tested by instrument users rather than by the instrument manufacturer. Subsequently, an important literature has emerged that analyzes the key benefits from and obstacles to user involvement in the innovation process (for an overview, see Henkel and von Hippel 2005). Laursen and Salter (2006) show that the two most important external sources of innovation among UK firms are "suppliers" and "clients or customers": $66 \%$ of the sample of UK manufacturing firms indicated clients or customers as a source of knowledge or information for innovation, and $16 \%$ indicated that they rated this source very highly. Also, both innovation and marketing scholars point to the potentially important role of customers and users in the innovation process. For example, Slater and Narver (1994) find a significant and positive main effect of "market orientation" (a construct that includes "customer orientation"; Narver and Slater 1990) on "new product success," and marketing research is in general broadly supportive of the link between market orientation and various innovation measures (Han et al. 1998, Hurley and Hult 1998, Lukas and Ferrell 2000). Han et al. (1998) empirically find support for the mediating role of innovation in the link between market orientation and corporate financial performance. 
In the present research, we focus on those firms that introduce innovations to end markets. A substantial part of the user innovation literature is preoccupied with understanding the circumstances in which users may be the initiators of what later become end-market innovations (von Hippel 1976, 1988, 2005). Indeed, von Hippel (2005) describes how user inventions are often invented, prototyped, and field tested by users, but then streamlined and introduced to the end market by established firms. Another part of the literature, with which the present paper is closely aligned, adopts a more strategic management perspective in terms of concern with how established firms can leverage interaction with users to increase innovation performance (e.g., Lilien et al. 2002, Neale and Corkindale 1998, Urban and von Hippel 1988). In this context, von Hippel and colleagues focus on lead users, that is, users who perceive needs at an earlier stage in time than other users and also are positioned to benefit considerably by achieving a solution. Interaction between firms and these knowledgeablesometimes even "tough"-customers (cf. Gardiner and Rothwell 1985), in which the customer provides important knowledge and information to the producer or directly participates in innovative activity, improves the resulting products or processes (Lilien et al. 2002, Rosenberg 1982). This part of the user innovation literature takes this interaction as the unit of analysis and examines, for example, how cooperation improves both the capacity of the customer firm to transmit the knowledge that may be useful in the innovation process and the capacity of the established firm to absorb it. The open innovation literature (Chesbrough 2003, Fey and Birkinshaw 2005, Gassmann 2006, Laursen and Salter 2006, Lichtenthaler 2008) explores how firms more generally can make use of external knowledge to improve their innovation performance.

In short, these literatures claim a direct link from interaction with customers and users to innovation performance. And such a link may indeed exist. For example, if research and development (R\&D) personnel directly responsible for the development and prototyping of new products and services are able to interact directly with key users, then there is a direct link. In that case, the organizational problem is limited to whether the R\&D personnel have an accurate understanding of customer/user needs and are motivated to react in a way that furthers their organization's goals. However, it may be that the contact with customers or users is with, for example, their key account managers. In this case, the organizational problem encompasses communication of the relevant knowledge to the appropriate employees and motivating the required behaviors. In this case, it is likely that different kinds of organizational structure and administrative mechanisms may mediate the link between user and customer knowledge to innovation rather differently. This warrants more in-depth examination of various organizational practices.

Unfortunately, the literatures referred to above are not completely forthcoming with respect to the types of organizational practices that firms need to adopt when interacting with entities external to the firm, such as customers, in the context of innovation. A partial exception is the market orientation literature, which sometimes includes organizational practices as an independent variable. For example, Slater and Narver (1994) build a market orientation construct that includes "interfunctional coordination," and they use it to explain new product development. However, this organizational practice is combined with other items to form a market orientation construct; thus, there is no causality postulated between organizational practices and market orientation. Hurley and Hult (1998) suggest that "participative decision making" may play a role in the link between market orientation and innovation performance but do not consider other organizational practices. Narver et al. (2004) include a measure of "bureaucratic organizational form" in their study but do not examine how this variable interacts with the customer orientation variable in explaining new product success. Grinstein (2008) conducts a meta-analysis of research on market orientation based on papers published over the period 1994-2006 and concludes that customer orientation and interfunctional coordination have independent explanatory power in explaining innovation consequences, but Grinstein does not consider how and why these two variables could be related in determining innovation outcomes. To be sure, although very valuable, these studies provide incomplete stories about how customer and user knowledge is leveraged in the context of innovation. In sum, although it has for long been known that producer firms need a certain degree of absorptive capacity to benefit from externally developed knowledge-including users' knowledge - the internal organizational dimensions of such absorptive capacity are unclear.

Inward- and Outward-Looking Absorptive Capacity In a seminal contribution, Cohen and Levinthal (1990, p. 128) identified absorptive capacity as a determinant of innovation performance, defining it as the "ability to identify, assimilate, and exploit knowledge from the environment." Most of the subsequent research on absorptive capacity focuses on knowledge-related antecedents to absorptive capacity (e.g., R\&D investments), and very little examines how absorptive capacity relates to organizational practices (but see Jansen et al. 2005, Volberda et al. 2010). Although Cohen and Levinthal (1990, p. 131) indicate that internal organization may matter for the identification, assimilation, and exploitation of external knowledge, they do not analyze in any great detail how and why organization matters. However, they introduce a useful distinction between "inward-looking" and "outward-looking" 
absorptive capacity. The former relates to the efficiency of the firm's internal communication, whereas the latter refers to its points of contact with external sources of knowledge (Cohen and Levinthal 1990, p. 133). This distinction provides a starting point for relating organizational practices to the successful use of external knowledge for the purposes of innovation. Specifically, organizational practices have inward-looking or outward-looking dimensions in the sense that some practices enhance the efficiency of internal communication whereas others help to establish points of contact with external sources of knowledge. These dimensions are likely to be complementary, because introducing outward-looking organizational practices makes it more profitable (within limits) to introduce inward-looking organizational practices, and vice versa. In other words, if a firm has in place a set of outward-looking organizational practices that allows it to detect and to interact with holders of pertinent knowledge such as customers, then the value of inward-looking organizational practices will be enhanced because they can be used also to diffuse the external knowledge within the organization. Likewise, the value of outward-looking organizational practices will increase if inward-looking organizational practices are in place.

\section{Organizational Practices}

Internal organization traditionally is described in terms of (combinations of) variables that relate to structure (e.g., specialization, departmentalization, liaison groups, hierarchical layers, etc.), communication channels, and reward systems (e.g., Burton and Obel 1998, Mendelson 2000, Roberts 2007, Tushman and Nadler 1978). Many of these variables are relevant to our understanding of how the knowledge residing in customers is linked to the innovation performance of those firms that interact with these customers. Specifically, organizational practices may hinder or facilitate interaction with customers. This is partly a structural issue; for example, in the case of traditional hierarchical structures that imply little delegation of decision rights to employees, it may be difficult to build close relations with customers and therefore will make it difficult for the firm to identify and get access to the knowledge held by these customers. Similarly, organizations may find it difficult to disseminate this knowledge across organizational structures consisting of (rigid) departments and specializations (Cohen and Levinthal 1990). Finally, the reward systems in these hierarchical structures are unlikely to ensure that the relevant knowledge moves to where it is needed, because they are designed for different purposes. Conversely, an internal organization that includes delegation of decision making, communication channels, and reward systems may be designed to facilitate interaction with customers and access to the knowledge held by customers and to create the conditions for transferring this knowledge within the firm and rewarding employees for behaviors that lead to knowledge being deployed in the context of innovation.

\section{User Innovation and New Organizational Practices}

We argue that "new organizational practices" may serve exactly these purposes. It has been shown that new organizational practices have the potential to promote improvements in innovative performance (e.g., Laursen and Foss 2003), productivity (e.g., Datta et al. 2005, Ichniowski et al. 1997), and profitability (e.g., Huselid 1995, Mendelson 2000). The studies cited all argue that these potential benefits can only be fully realized if firms introduce a set of mutually reinforcing (i.e., complementary) organizational practices.

The literature on these practices and their form is extensive and identifies many specific new organizational routines, such as communities of practice, corporate venturing, project organization, total quality management, etc. New organizational forms represent new ways of linking decision delegation, communication channels, reward systems, and arrangements geared toward achieving high levels of organizational performance (Child and McGrath 2001, Colombo and Delmastro 2002, Zenger and Hesterly 1997). Table 1 maps the key contributions to the new organizational practices and market orientation literatures; it highlights their main constructs and shows how they map into delegation, internal communication, and incentive systems and a residual category ("other organizational variables"). Table 1 provides support for the conclusion in Guthrie (2001, p. 181) that "[t]he common theme in this literature is an emphasis on utilizing a system of management practices giving employees skills, information, motivation, and latitude and resulting in a workforce that is a source of competitive advantage." In this research, we focus only on work practices that enhance internal information flows and give motivation (incentives) and latitude (delegation), and ignore practices designed to improve employees' skills (especially training and recruitment and retention practices, which appear in the residual category in Table 1). We make this choice to concentrate on a narrower set of practices, making the analysis more manageable. Moreover, the focus on delegation, internal communication, and incentives allows for a focus on the factors that directly affect the behavior of given employees. Improving the skills of the pool of employees is much more long term in nature and is not so directly related to social behavior within the organization. Table 1 also shows that the literature considers different types of incentives; in this paper, because of our focus on innovation, we concentrate on "knowledge incentives" (i.e., incentives for acquiring and sharing knowledge).

We build on the insights of this literature and posit that new organizational practices have additional effects 


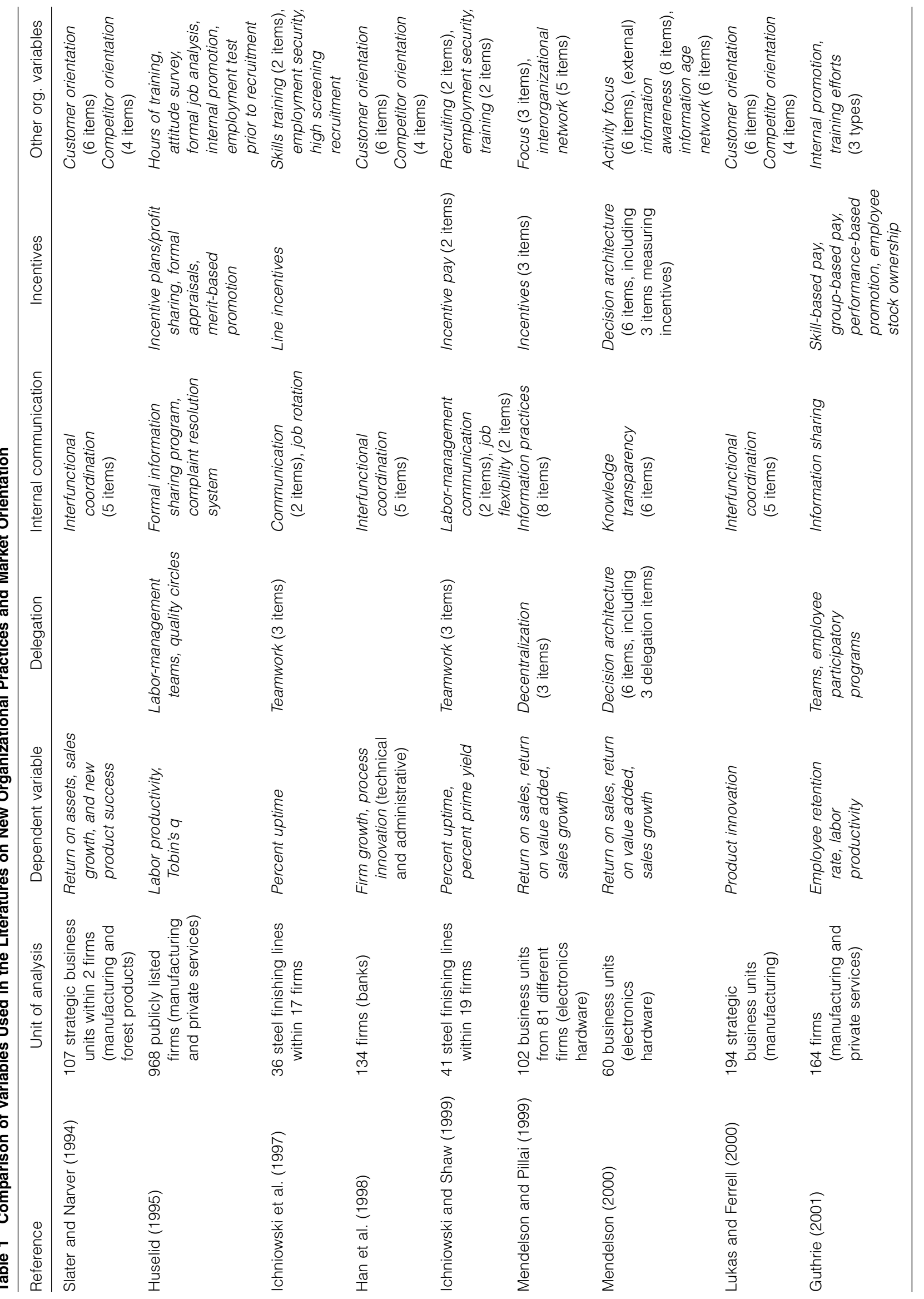




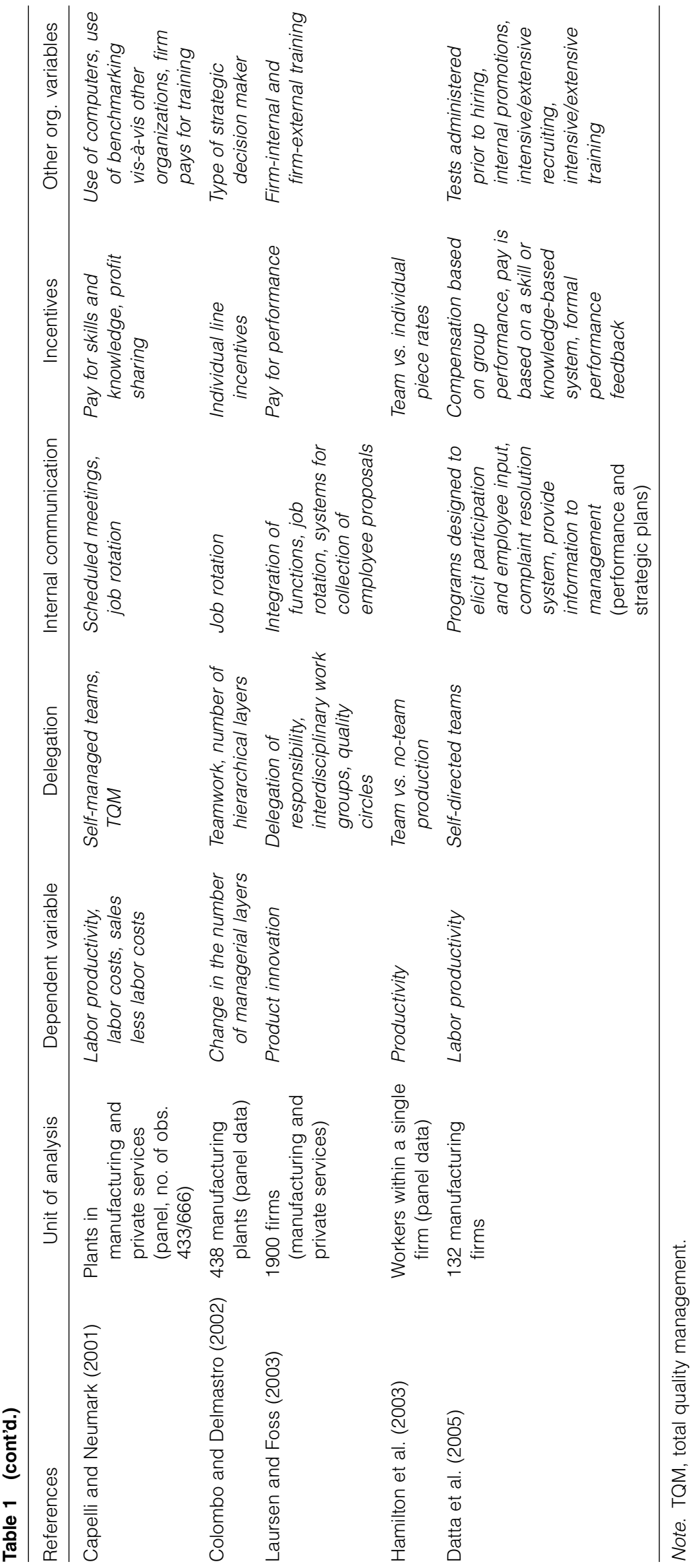


relative to those identified in the literature: delegating decision rights, supporting vertical and lateral communication, and incentivizing knowledge acquisition and sharing can help firms to better identify, assimilate, and exploit knowledge from the external environment to become more innovative. Firms seem aware that their organizational practices influence their sourcing of external knowledge. For example, Dougherty (2001, p. 625) cites a marketing manager at Texco reflecting on organizational changes designed to accomplish this aim:

I came to this business seven years ago. It had a traditional organization with director of development [technology] and a bunch of engineers, and a marketing manager and salesmen. The salesmen would go and find customers and get a quote on a product, and bring it back and drop it in a box, and the engineers would pick them up and do them. The salesman would go back to the customer and show it to them and say "is this OK?" We were doing hundreds of these costings, and very few of them would get to the sample stage, and of those, very few succeeded. Our hit rate was very low.... Everything the engineers worked on was screened through the sales people, and they never heard the voice of the customer.... Now the new ventures team develops new markets and innovations, and pulls in people from across the organization.... [Consider] the weaving, dyeing, and finishing plants. We help them understand the needs and the wants, do the QFDs [quality function deployments], have the manufacturing people help with the QFDs, and the development engineers take the process engineers to several customers.

In this example, decision rights to "pull in people from across the organization" were delegated to a new ventures team, and development engineers were able to make the decision to "take the process engineers to several customers." This reallocation of decision rights was explicitly to improve the sourcing and use of knowledge held by customers. Nevertheless, to access customer knowledge, such changes need to be complemented with other organizational practices if the knowledge is to exploited successfully for innovation. Specifically, we argue that firms need to increase internal communication and to motivate knowledge acquisition and sharing and dissemination of the relevant knowledge inside the organization, enabling the combination and recombination of knowledge.

\section{Theoretical Model and Hypothesis}

In the following, we develop a set of hypotheses concerning the mediating role of new organizational practices with respect to linking the knowledge held by firm customers to the firm's innovation performance. The theoretical model presented in Figure 1 summarizes our key constructs and the hypotheses we develop concerning their relations.

\section{Interaction with Customers and Innovation Performance}

Although our focus in this paper is on understanding how established firms can choose organizational practices that allow them more efficiently to tap and exploit the knowledge that resides with their customers, the part of the sources of innovation literature that focuses on users as the loci of innovation is also relevant because it helps to explain why users, including customers, often play a central role in the preliminary stages of the innovation process. According to this stream of research, there are two main reasons why users/customers contribute to the innovation process. First, in many cases they will be the main beneficiaries of the innovation (von Hippel 1988). For example, an airline may gain competitive advantage from being the first adopter of a newly developed fuel-efficient airplane. Thus, the airline has an incentive to codevelop the plane with the airplane producer (cf. Rosenberg 1982). ${ }^{2}$ Second, customers often posses "sticky" knowledge (i.e., knowledge that is costly to transfer) (von Hippel 1998).

Stickiness may be due to various knowledge attributes, such as the way it is encoded (tacit or codified), or it may be caused by the attributes of the agents seeking or providing the knowledge (e.g., their cognitive capacity and motivation). Thus, the airline may possess knowledge about the performance and operating characteristics of a plane that may be an essential input for the modification to the airplane. However, this knowledge may be dispersed among a number of the airline's employees (who may have no incentive to share it) and will probably have a considerable "tacit" component (which impedes its articulation). Mobilizing this knowledge so that it can serve as an input to the innovative process requires direct collaboration between the airline and the producer (Rosenberg 1982, p. 124). From the point of view of the producer firm, the stickiness of knowledge implies that it will be advantageous to collaborate with its customers (and users more broadly), because this will allow access to knowledge that the firm would be unable to produce in-house-knowledge that may prove critical to innovation success (Gardiner and Rothwell 1985, Neale and Corkindale 1998, Pavitt 1984, Rothwell et al. 1974) and for the firm's subsequent competitive advantage (Desouza et al. 2008, Lilien et al. 2002). However, getting access to this knowledge requires honing the capabilities for cooperating (e.g., Dyer and Nobeoka 2000, Dyer and Singh 1998). We build on the strategic management-oriented arguments in the user innovation literature as well as arguments in the marketing literature (e.g., Slater and Narver 1994) and accept that customers are an important source of the knowledge that forms the basis of innovation. This overall insight motivates the following hypothesis.

HYPOTHESIS 1 (H1). The more the focal firm engages in interaction with customers, the better will be its innovation performance. 
Figure 1 Theoretical Model

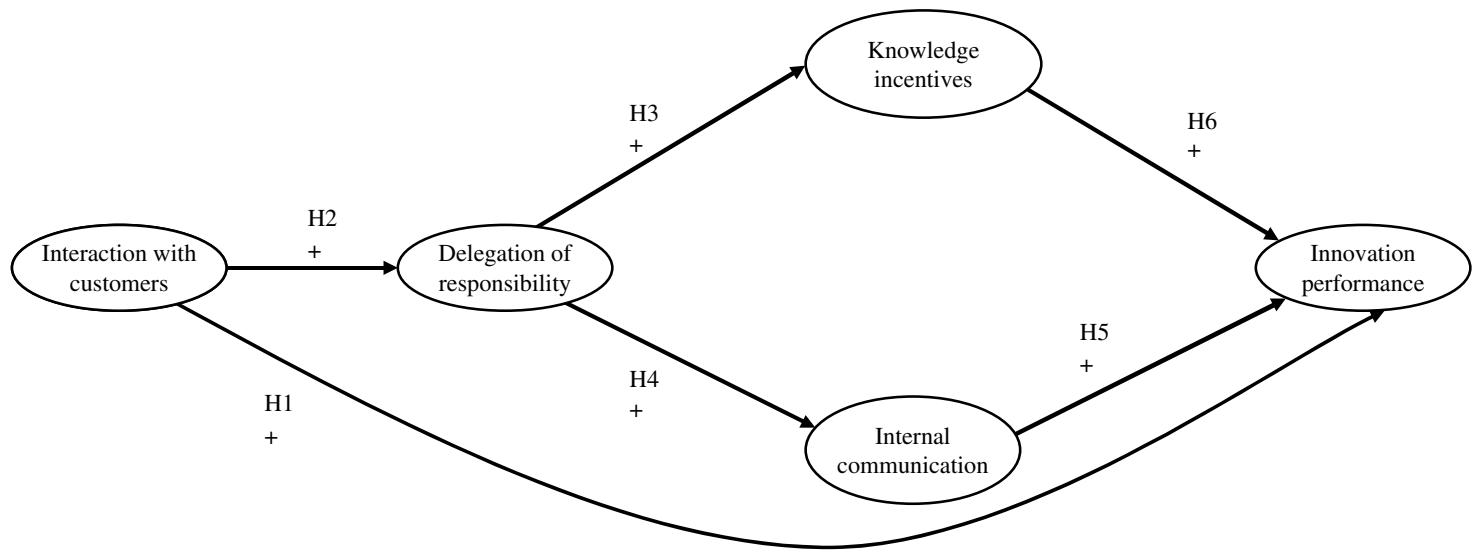

The literature underlying Hypothesis 1 asserts that there is a direct link from customers and users to innovation performance, for example, because users directly cooperate with R\&D personnel. However, it is also possible that customer knowledge enters the firm in other ways than via the R\&D function. This raises the issue of which organizational practices should be introduced to increase the probability that use will be made of this knowledge in the context of innovation.

\section{New Organizational Practices: The Link Between User Interaction and Innovation Performance}

It is generally recognized that "[i]nformation and knowledge are at the heart of organizational design" (Holmström and Roberts 1998, p. 90), and that firms can design their organizations to promote the sharing and recombination of knowledge resources (Foss 2003, Laursen and Foss 2003, Mendelson and Pillai 1999, Nickerson and Zenger 2004, Osterloh and Frey 2000). As pointed out earlier, we extend this perspective to the context of exploiting customers' knowledge in the innovation process and discuss how various new organizational practices can assist firms to leverage the knowledge held by customers in the context of innovation.

Delegation as an Outward-Looking Organizational Practice. The literature provides a number of cognitive and motivation reasons why firms delegate decision rights to employees. Thus, according to classical organization theory, delegation economizes on managers' scarce mental resources and reduces the costs of transmitting, receiving, and processing information (Galbraith 1974). On a related note, delegation may colocate decision-making rights with those who possess the knowledge about what decision should (optimally) be made (Jensen and Meckling 1992); communicating this knowledge to hierarchical superiors may be costly and too slow. It has been argued that a fast-moving external environment makes extensive delegation increasingly pressing because slow decision making will be punished in such environments (Mendelson and Pillai 1999, Zenger and Hesterly 1997).

A further reason why firms engage in extensive delegation of decision rights is related to the interactions with customers for the purposes of gaining access to valuable customer knowledge. Some employees, by virtue of their job descriptions, have automatic rights to interact with outside parties, for example, managers responsible for customer relations. Some firms have "gatekeepers" (Allen 1977, Allen and Cohen 1969, Tushman and Katz 1980) that connect research teams with external sources of knowledge while also filtering out noise. Delegation of responsibility is important for absorbing knowledge and information from customers: in information-rich environments, gatekeepers-and other staff working directly with customers-need to be able to make decisions with respect to the direction of an innovation project because they are the people best able to judge, absorb, and pass on the inputs from customers. In other words, one reason for delegating decision rights to employees working with customers/users is that these employees will often have specific knowledge concerning customers and their ideas that is superior relative to that of the firm's management team. As such, delegation is an outward-looking organizational practice. Firms also may actively encourage employees other than gatekeepers and technical staff to seek information about market and technological trends, notably by interacting with customers, and to disseminate this knowledge internally (Matusik 2002).

With respect to motivation, delegation is often argued to increase the motivation for many (if not necessarily all) employees (e.g., Deci 1975, Gagné and Deci 2005, Porter and Lawler 1968). Delegation thus has the dual effect that it empowers employees to make active efforts to identify and assimilate external knowledge and provides an incentive to actually engage in this activity. In sum, extensive delegation of decision rights is an organizational practice that firms can implement to improve 
the identification of external knowledge that is potentially useful in the context of innovation. This reasoning motivates the following hypothesis.

HYPOTHESIS $2(\mathrm{H} 2)$. The more the focal firm interacts with its customers, the more it will delegate responsibility.

Communication and Knowledge Sharing as InwardLooking Organizational Practices. Interaction with customers in the context of innovation involves the transfer or exchange of often large amounts of customer knowledge and information. It is often crucial that the knowledge or information transferred into the firm is distributed to other parts of the firm (Haefliger et al. 2008). Apart from the obvious case of best-practice transfer, in complex technical products it is important to transfer knowledge about modifications that relate to several different components in the product (Baldwin and Clark 2000). The need for intensive internal sharing and communication of knowledge from customers would seem to be particularly important when it is related to product architecture. ${ }^{3}$ Knowledge that is transferred between customer and firm and which concerns a complex product and/or has architectural elements is likely to require intensive interaction between the two parties, but may require substantial interaction within the firm as well. The latter aspect will require internal communication not only of the knowledge that relates to individual components, but also about how components are related in an architecture (Baldwin and Clark 2000).

Save for the rare cases where the people who identify potentially valuable external knowledge are those responsible for applying it in an innovation, this knowledge will have to be communicated to all of the firm's units, departments, and staff involved in the innovation process. There are some well-known barriers to internal knowledge transfer (e.g., Cohen and Levinthal 1990, Lynex and Layzell 1998) that can be reduced through the adoption of certain organizational practices. Specifically, firms that adopt outward-looking organizational practices (i.e., delegation of responsibility), for example, to get access to the knowledge held by customers should also adopt inward-looking organizational practices. Two highly relevant inward-looking new organizational practices are (1) provision of knowledge incentives, i.e., rewarding employees for knowledge acquisition and sharing; and (2) internal communication in the vertical and horizontal dimensions, including knowledge sharing. Thus, given that the adoption of outward-looking organizational practices (delegation of responsibility) positively affects the adoption of inwardlooking organizational practices, we propose the following two hypotheses.

Hypothesis 3 (H3). The more the focal firm delegates responsibility, the more it will use knowledge incentives.
Hypothesis $4(\mathrm{H} 4)$. The more the focal firm delegates responsibility, the more communication will take place inside it.

Kogut and Zander (1992) argue that innovations are the product of a firm's "combinative capabilities" to generate new applications from existing knowledge where the working of such capabilities is mediated by the presence of shared knowledge (see also Dougherty 2001). In this view, firms can gain competitive advantage through the ability to create and share knowledge more efficiently than competitors. A recent literature builds on network theory and the concept of social capital to examine how intraorganizational channels of communication positively mediate the relation between knowledge and outcomes such as product innovation (Hansen 1999, Tsai 2001, Tsai and Ghoshal 1998). Another research stream looks specifically at product innovation and examines the impediments to knowledge transfer among subunits within the firm (Henderson and Cockburn 1994, Leonard-Barton and Sinha 1993, Szulanski 1996). It is argued that close and frequent interactions between R\&D and other functions, teams, and subunits lead to superior innovation performance because they lead to better integration and coordination of different bodies of knowledge (cf. Aoki 1986). Accordingly, we hypothesize the following.

Hypothesis 5 (H5). The more the focal firm engages in internal communication, the higher will be its innovation performance.

Paying Employees to Acquire and Share Knowledge. Knowledge acquisition and knowledge sharing behaviors are playing an increasing part in firms' performance measurement and reward systems (Laudon and Laudon 2002). They may be (but often are not) part of a formal knowledge management program and are introduced on the grounds that if employees are rewarded for upgrading and sharing knowledge, they will do so, and may also actively try to seek out shareable knowledge (e.g., from customers). ${ }^{4}$ Rewarding knowledge acquisition and sharing behavior compensates for the effort required to seek and share knowledge and also perhaps surrender potentially valuable bargaining chips (Brynjolfsson 1994). To the extent that such rewards have the intended effect, they may be seen to be outward- as well as inward-looking organizational practices, because they not only motivate employees to share knowledge they already hold, but they also encourage the identification and assimilation of new knowledge (that can be shared later). Accordingly, we propose the following hypothesis.

Hypothesis 6 (H6). The more the focal firm uses knowledge incentives, the higher will be its innovation performance. 


\section{Methods}

\section{Sampling and Data}

Our sampling frame is a group of Danish firms. The data were collected in a survey, conducted in 2001, of the 1,000 largest firms in Denmark. Although smaller firms also engage in interactions with customers, in the context of this paper, a focus on the largest firms is sensible because the largest firms in Denmark are arguably disproportionately more engaged in innovation activities and more likely to have adopted organizational practices of knowledge sharing, delegation, and incentive pay to facilitate innovation.

The research team developed the questionnaire during January to June 2001. To the extent possible, the questions were based on previous studies of organizational and human resource management practices, notably the scales developed by Lawler et al. (1998, pp. 200-223). In June 2001, a private consultancy firm (PLS Rambøll) pretested the questionnaire; as a result, some questions were revised to improve their clarity. In August 2001, PLS Rambøll administered the questionnaire to the 1,000 target firms. After two reminders, a total of 207 firms had responded to the survey, a response rate of $21 \%$. However, because of missing answers, only 169 responses were usable for statistical analysis. The questionnaires were responded to by chief executive officers in most cases; in some, the respondent was the human resources manager or another top manager. The 169 firms included in the data set have an average of 1,811 employees, with wide variation between some very large firms at one end of the spectrum and a number of smaller firms with approximately 350 employees at the other end. On average, $28 \%$ of their sales are made abroad, which indicates that they are highly internationally oriented.

Nonresponse biases were evaluated by comparing the industries represented in the sample with the population sample used. Applying a chi-square test, we cannot reject the hypotheses that the distribution of firms across industries is equal between our sample and the overall population at any reasonable level of significance (at both the one- and two-digit Danish industry code levels). In addition, we applied $t$-tests comparing our sample and population means with respect to variables such as total sales (a measure of firm size), profits, and year of firm foundation. For total sales, we find that the two groups are virtually identical, whereas in terms of profits, respondents are slightly less profitable than nonrespondents (difference significant only at the $10 \%$ level). Similarly, on average, there is a weak tendency (difference significant only at the 10\% level) for responding firms to have been longer established than nonrespondents (1956 versus 1964). However, overall, there seems to be broad correspondence between the underlying population and our sample. It should be noted, however, that although the population and the sample largely correspond on these objective variables, we cannot rule out there being differences with respect to some of the questionnaire-based variables of interest in this study.

\section{Measures and Operationalization}

We use perceptual measures to operationalize the variables in this research. Below, we describe how constructs were operationalized and evaluate the different forms of validity.

Interaction with Customers. This construct mirrors the extent to which the focal firm involves customers in its innovation activities. It includes three items measured on a seven-point Likert-type scale from 1 (not at all) to 7 (to a very large extent). For the first two items, we asked managers to what extent they were (1) involving customers in close collaboration on development projects and (2) communicating intensively with customers. For the third item, we asked to what extent the overall strategy of the firm emphasizes close collaboration and dialogue with customers. Together, the responses indicate the degree of involvement of customers in innovation activities.

Delegation. Delegation reflects the extent to which responsibilities and decision rights are delegated to employees. The construct is based on two items. On the first item we asked to what extent employees can influence their own job (measured on a seven-point Likerttype scale, with 1 being "not at all" and 7 being "to a very large extent"). The second item is a measure of the number of employees that are engaged in teams with a high degree of autonomy $(1,0 \% ; 2,1 \%-25 \% ; 3$, $26 \%-50 \% ; 4,51 \%-75 \% ; 5,76 \%-99 \% ; 6,100 \%)$. The first item captures delegation of responsibility toward the individual, whereas the second item refers to delegation at team/group level. Together, these two items form a construct for the level of delegation in the firm.

Knowledge Incentives. This construct measures to what extent employees' salaries are associated with acquiring knowledge and knowledge sharing. Managers were asked to indicate on a seven-point Likert-type scale ( 1 , not at all; 7 , to a very large extent) the extent to which (1) an employee's salary is linked to the ability and willingness to share knowledge and (2) the salary is linked to the willingness to improve skills and upgrade knowledge. The latter investigates searching for rather than sharing knowledge (improving skills and upgrading knowledge is related more to receiving than transferring knowledge). Moreover, we expect that in an organizational setting, sharing of and searching for knowledge would be related in the sense that a successful knowledge search is, to an extent, a positive function of the extent to which one shares knowledge with colleagues. 
Internal Communication. This construct reflects communication within the firm, across the lateral as well as hierarchical dimensions. It is measured by two items that asked respondents to indicate the extent to which (1) employees exchange information between different functional departments and (2) there is communication between management and employees. Both items were measured on a seven-point scale, ranging from 1 for "not at all" to 7 for "to a very large extent."

Innovation Performance. This construct is based on two items. Managers were asked to indicate the performance of the focal firm compared with competitors on the following two dimensions: (1) innovation capacity and (2) profitability (both measured on a seven-point scale ranging from 1 for far below average to 7 for far above average). The argument for including profitability to measure innovation performance is that the Schumpeterian (Schumpeter 1912/1934) notion of innovation pertains not only to the capacity to introduce "new combinations," for instance, in terms of new products but also to the economic significance of those new products. Success will be reflected in higher profits. Moreover, the empirical literature points to the fact that innovations and profitability are intrinsically linked (see, for instance, Geroski et al. 1993).

\section{Construct Analysis}

The hypotheses are tested in a LISREL model that allows for simultaneous formation of underlying constructs (measurement model) and tests structural relationships among these constructs (structural model). The advantage of applying a LISREL model for the estimation, rather than regression analysis, is twofold. First, the model allows us to deal with complex mediated relationships, which are central to this paper and are cumbersome to deal with in a regression setup. Second, unlike regression analysis, a LISREL model accounts for measurement error in the presence of latent variables represented by a set of items. A disadvantage of LISREL models is that control variables cannot be included in the conventional way enabled in regression models. For instance, dummy variables cannot be included, and it is practically impossible to include control variables that contribute little to the overall model (Fletcher et al. 2006). However, we use "group analysis" to test for interaction effects among group variables (Jaccard and Wan 1996). The validity of LISREL models is estimated by the validity of the entire model, that is, by its nomological validity. However, before estimating the nomological validity of the model with the causal relations specified, it is important to judge its convergent validity, that is, the homogeneity of the constructs included in the model and its discriminant validity, or the extent the constructs are independent (Campbell and Fiske 1959).
Measurement Model. We create a measurement model to assess convergent and discriminant validity. Table 2 reports the means, standard deviations, and correlations among all variables. The correlations provide initial evidence of high levels of convergent (i.e., high correlations among items belonging to the same construct) and discriminant validity (i.e., lower correlations with items belonging to other constructs). In fact, the coefficients among the items that belong to the same construct vary between 0.38 and 0.64 (highlighted in bold), whereas none of the other coefficients exceeds 0.34 .

Convergent Validity. To ascertain whether the constructs are internally coherent, we conducted several tests of convergent validity. These are reported in Table 3, which is based on the saturated measurement model where all interfactor correlations are specified (Jöreskog and Sörbom 1993). First, Table 3 shows the strength of the linearity in relations between constructs and items-the $R$-squared values. In all cases, the strength of the linearity is relatively strong with a $R$-squared value of 0.36 or above. This is clearly above the usual threshold of 0.20 for the $R$-squared value (Hair et al. 1995). Table 3 also allows us to conclude that the $t$-values for all items are highly significant (i.e., all are above 4.74) and that their (standardized) factor loadings are strong (all above 0.60). Second, the reliability of each construct is calculated, and all are above the recommended threshold of 0.70 (Gerbing and Anderson 1988). Also, when we consider extracted variance, the picture improves: all constructs are above the recommended threshold of $0.50(0.52-0.61)$.

Discriminant Validity. Several measures of discriminant validity were obtained from the data. Discriminant validity tests whether the correlations and causal paths between the latent constructs are significantly different from 1 (e.g., Burnkrant and Page 1982). Constructing $99.9 \%$ confidence intervals around the correlations and causal paths confirms that none of them is close to 1. Fornell and Larcker (1981) suggest a comparison between the variance extracted for each construct and the variance shared between constructs (the squared correlations between the constructs). These are presented in Table 3, which shows that the variance extracted is clearly higher than the variance shared for all constructs. In combination, these tests indicate that the discriminant validity of the five constructs is very satisfactory.

Common Method Bias. Research involving crosssectional data, such as those collected in this study, is vulnerable to common method bias/variance. We took some precautions against this when designing the questionnaire by positioning the performance variables after the independent variables to reduce, if not avoid completely, the effects of consistency artifacts (Salancik and Pfeffer 1977). We also perform a common method bias 
Table 2 Means, Standard Deviations, and Correlations for Variables Used in the Study

\begin{tabular}{|c|c|c|c|c|c|c|c|c|c|c|c|}
\hline & 1 & 2 & 3 & 4 & 5 & 6 & 7 & 8 & 9 & 10 & 11 \\
\hline $\begin{array}{l}\text { (1) Customers involved } \\
\text { in close collaboration }\end{array}$ & 1.00 & & & & & & & & & & \\
\hline $\begin{array}{l}\text { (2) Intense communication with } \\
\text { customers }\end{array}$ & $0.50^{* * *}$ & 1.00 & & & & & & & & & \\
\hline $\begin{array}{l}\text { (3) Strategy of close collaboration } \\
\text { with customers }\end{array}$ & $0.38^{* * *}$ & $0.39^{* * *}$ & 1.00 & & & & & & & & \\
\hline $\begin{array}{l}\text { (4) Employees engaged in teams } \\
\text { with high degree of autonomy }\end{array}$ & $0.17^{*}$ & 0.09 & 0.04 & 1.00 & & & & & & & \\
\hline (5) Employees influence on own job & $0.25^{* *}$ & $0.24^{* *}$ & $0.25^{* * *}$ & $0.39^{* * *}$ & 1.00 & & & & & & \\
\hline $\begin{array}{l}\text { (6) Salary associated with the } \\
\text { ability and willingness to } \\
\text { share knowledge }\end{array}$ & $0.26^{* * *}$ & $0.32^{* * *}$ & $0.18^{* *}$ & $0.24^{* * *}$ & $0.34^{* * *}$ & 1.00 & & & & & \\
\hline $\begin{array}{l}\text { (7) Salary determined by the } \\
\text { willingness to improve skills and } \\
\text { upgrade knowledge }\end{array}$ & $0.21^{* *}$ & $0.26^{* * *}$ & $0.21^{* * *}$ & $0.28^{* * *}$ & $0.28^{* * *}$ & $0.64^{* * *}$ & 1.00 & & & & \\
\hline $\begin{array}{l}\text { (8) Exchange of information between } \\
\text { employees across departments }\end{array}$ & 0.07 & 0.08 & 0.10 & $0.15^{* *}$ & $0.33^{* * *}$ & $0.29^{* * *}$ & $0.20^{* *}$ & 1.00 & & & \\
\hline $\begin{array}{l}\text { (9) Communication among employees } \\
\text { and management }\end{array}$ & 0.10 & $0.24^{* * *}$ & $0.15^{*}$ & $0.16^{* *}$ & $0.32^{* * *}$ & $0.26^{* * *}$ & $0.22^{* * *}$ & $0.42^{* * *}$ & 1.00 & & \\
\hline $\begin{array}{l}\text { (10) Innovation capacity performance } \\
\text { relative to competitors }\end{array}$ & 0.08 & $0.14^{*}$ & 0.08 & $0.16^{* *}$ & $0.28^{* * *}$ & $0.26^{* *}$ & $0.24^{* * *}$ & $0.17^{* *}$ & $0.27^{* * *}$ & 1.00 & \\
\hline (11) Profitability relative to competitors & 0.09 & 0.06 & -0.02 & $0.15^{*}$ & $0.23^{* * *}$ & $0.23^{* *}$ & $0.16^{* *}$ & $0.17^{* *}$ & $0.28^{* * *}$ & $0.42^{* * *}$ & 1.00 \\
\hline Mean & 4.21 & 5.32 & 6.26 & 3.07 & 4.97 & 3.71 & 4.32 & 4.71 & 5.53 & 5.04 & 5.15 \\
\hline Std. dev. & 1.84 & 1.40 & 0.96 & 1.41 & 1.28 & 1.61 & 1.44 & 1.39 & 0.97 & 1.55 & 1.17 \\
\hline Min & 1 & 1 & 1 & 1 & 1 & 1 & 1 & 2 & 2 & 1 & 2 \\
\hline Max & 7 & 7 & 7 & 6 & 7 & 7 & 7 & 7 & 7 & 7 & 7 \\
\hline
\end{tabular}

Note. Coefficients belonging to the same construct are highlighted in bold

${ }^{*}$ Significant at $5 \%,{ }^{* *}$ significant at $1 \%$, and ${ }^{* * *}$ significant at $0.1 \%$.

test, specifically, the single-factor procedure based on confirmatory factor analyses (see Podsakoff et al. 2003). We examine the fit of the single-factor model in which all items are loaded onto one factor to address the problem of common method variance. The logic underlying the single-factor procedure is that if method variance is responsible for most of the covariation among the constructs, confirmatory factor analysis should indicate that a single-factor model fits the data. Goodness-of-fit index (GFI) statistics for the single-factor model are presented in Table 4: a GFI of 0.57 and root mean square error of approximation (RMSEA) of 0.23 are not very representative of the data. In fact, the single-factor model is highly insignificant and can clearly be rejected. The improved fit of the alternative and more complex models listed in Table 4, compared with the simpler models, is statistically significant. Although this statistical test does not eliminate the threat of common method variance, it provides evidence that interitem correlations are not driven solely by common method bias. In our ordinary least squares regression robustness checks (see below), we conduct an analysis (not presented here for reasons of space but available from the authors upon request) involving marker variables (Lindell and Whitney 2001, Podsakoff et al. 2003). Although these marker variables in some cases have separate explanatory power, they do not remove the significance of our key variables.
Structural Model. The second step in the analytical process is to form the structural model by specifying causal relations based on the hypotheses. The LISREL analysis is conducted iteratively to fine-tune the model to obtain more coherent representation of the empirical data. The LISREL analysis is aimed at confirming a model based on specified causal relations. The test consists of generating a structural model that includes relationships that accord with the hypotheses (see Figure 1). We test single causal relations with $t$-values and factor loadings between the model constructs. GFI values are critical for an evaluation of the entire model. However, given their complexity, there is no consensus regarding the "best" index of overall fit for structural equations. Thus, reporting of multiple indexes is recommended (Bollen 1989).

Goodness of Fit. We assessed the entire model by different goodness-of-fit measures including the chi-square value, the GFI, and the nonnormed fit index, which are measures of the distance between the data and the model, i.e., nomological validity (Jöreskog and Sörbom 1993). The model has a chi-square value of 37.14 for 38 degrees of freedom $\left(\chi_{(38)}^{2}=37.14, p=0.51\right)$, providing strong evidence that we cannot reject the hypothesis that the estimated model does not differ from the data. In other words, this finding is consistent with the idea that the model provides a good representation of the data; thus, there is no significant statistical difference between 
Table 3 Constructs and Items

\begin{tabular}{|c|c|c|c|c|c|c|}
\hline Constructs and items & Factor loading & $t$-value & $R^{2}$-value & Construct reliability & $\begin{array}{l}\text { Variance extracted } \\
\text { by constructs }\end{array}$ & $\begin{array}{l}\text { Variance shared } \\
\text { between constructs }\end{array}$ \\
\hline Interaction with customers & & & & 0.76 & 0.52 & 0.34 \\
\hline $\begin{array}{c}\text { Customers involved in } \\
\text { close collaboration }\end{array}$ & 0.71 & 6.75 & 0.50 & & & \\
\hline $\begin{array}{l}\text { Intense communication } \\
\text { with customers }\end{array}$ & 0.84 & 9.31 & 0.71 & & & \\
\hline $\begin{array}{l}\text { Strategy of close collaboration } \\
\text { with customers }\end{array}$ & 0.60 & 5.64 & 0.36 & & & \\
\hline Delegation & & & & 0.71 & 0.55 & 0.34 \\
\hline $\begin{array}{l}\text { Employees have influence } \\
\text { on their own job }\end{array}$ & 0.77 & 8.16 & 0.59 & & & \\
\hline $\begin{array}{l}\text { Employees engaged in teams } \\
\text { with high degree of autonomy }\end{array}$ & 0.71 & 5.26 & 0.50 & & & \\
\hline Knowledge incentives & & & & 0.76 & 0.61 & 0.28 \\
\hline $\begin{array}{l}\text { Salary associated with } \\
\text { the ability and willingness } \\
\text { to share knowledge }\end{array}$ & 0.81 & 10.37 & 0.66 & & & \\
\hline $\begin{array}{l}\text { Salary determined by the } \\
\text { willingness to improve } \\
\text { skills and upgrade knowledge }\end{array}$ & 0.75 & 9.76 & 0.57 & & & \\
\hline Internal communication & & & & 0.70 & 0.54 & 0.28 \\
\hline $\begin{array}{l}\text { Exchange of information between } \\
\text { employees across departments }\end{array}$ & 0.69 & 5.53 & 0.48 & & & \\
\hline $\begin{array}{l}\text { Communication among employees } \\
\text { and management }\end{array}$ & 0.78 & 7.33 & 0.61 & & & \\
\hline Innovation performance & & & & 0.72 & 0.56 & 0.14 \\
\hline $\begin{array}{l}\text { Innovation capacity of focal } \\
\text { firm compared to competitors }\end{array}$ & 0.79 & 4.74 & 0.62 & & & \\
\hline $\begin{array}{l}\text { Profitability of focal firm } \\
\text { compared to competitors }\end{array}$ & 0.71 & 4.86 & 0.50 & & & \\
\hline
\end{tabular}

Notes. Factor loadings are provided for the saturated measurement model where all possible interfactor correlations are specified. All factor loadings are highly significant at $p<0.01$ with a $t$-value above 3.30 .

our theory-based model and the original data, indicating that we explained the original correlations at a level not statistically different from the value of 1 . The GFI, which is based on residuals, shows a value of 0.96 , which represents a very good fit (suggested GFI $>0.90$ ) between the model and the data (Bollen 1989). Finally, the Bentler-Bonett normed fit index (NFI) represents the proportion of improvement in fit relative to the null model while controlling for model parsimony. The value obtained (NFI, 0.91) represents a good fit between model and data. In sum, all three fit indices indicate good fit of the proposed model to the data.

Table 4 Goodness-of-Fit Statistics for Competing Specifications of the Model

\begin{tabular}{|c|c|c|c|c|c|}
\hline & $\begin{array}{c}\text { Measurement } \\
\text { model }\end{array}$ & $\begin{array}{c}\text { Single-factor } \\
\text { model }\end{array}$ & $\begin{array}{c}3 \\
\text { Direct links } \\
\text { (no mediation) } \\
\text { I, D, S, C } \rightarrow \text { P }\end{array}$ & $\begin{array}{c}4 \\
\text { Partial mediation } \\
\mathrm{I} \rightarrow \mathrm{D} \\
\mathrm{D} \rightarrow \mathrm{S}, \mathrm{C} \\
\mathrm{I}, \mathrm{D}, \mathrm{S}, \mathrm{C} \rightarrow \mathrm{P}\end{array}$ & $\begin{array}{c}5 \\
\text { Full mediation } \\
\mathrm{I} \rightarrow \mathrm{D} \\
\mathrm{D} \rightarrow \mathrm{S}, \mathrm{C} \\
\mathrm{S}, \mathrm{C} \rightarrow \mathrm{P} \\
\end{array}$ \\
\hline \multirow[t]{3}{*}{ Chi-square (df) } & 33.50 & 408.20 & 160.60 & 36.60 & 37.10 \\
\hline & (34 df) & $(44 \mathrm{df})$ & (40 df) & (37 df) & (38 df) \\
\hline & $p=0.49$ & $p<0.001$ & $p<0.001$ & $p=0.49$ & $p=0.52$ \\
\hline GFI & 0.96 & 0.57 & 0.82 & 0.96 & 0.96 \\
\hline GFI adjusted for df & 0.93 & 0.36 & 0.71 & 0.93 & 0.93 \\
\hline Parsimonious GFI & 0.60 & 0.46 & 0.60 & 0.65 & 0.68 \\
\hline RMSEA & 0.01 & 0.23 & 0.14 & 0.01 & 0.00 \\
\hline Comparative fit index & 0.99 & 0.43 & 0.66 & 0.98 & 0.99 \\
\hline NFI & 0.92 & 0.36 & 0.61 & 0.91 & 0.91 \\
\hline Parsimonious NFI & 0.57 & 0.31 & 0.44 & 0.61 & 0.64 \\
\hline
\end{tabular}

Note. I, interaction with customers; D, delegation of responsibility; S, salaries linked to knowledge sharing; C, internal communication; $\mathrm{P}$, innovation performance; df, degrees of freedom. 
Furthermore, if we compare the estimated path model with the (saturated) measurement model, we find that the estimated path model fits the data better than the measurement model (an increase in the chi-square value of $\Delta \chi^{2}=3.6$, but with the use of four fewer degrees of freedom). The parsimonious GFI is 0.60 for the measurement model but increases to 0.66 for the estimated model. This is further evidence that the estimated model is superior to the measurement model.

\section{Results}

\section{Findings}

The figures given for the estimated path and structural models (see Figure 2) are standardized factor loadings of causal relations with $t$-values in parentheses (figures in bold relate to the structural model).

With respect to Hypothesis 1 ("The more the focal firm engages in interaction with customers, the better will be its innovation performance"), the relevant parameter estimate is insignificant ( $t$-value of -0.84$)$, so the hypothesis is rejected. This implies that interaction with customers is not a sufficient condition for securing innovative performance.

For Hypothesis 2 ("The more the focal firm interacts with its customers, the more it will delegate responsibility"), the results are consistent with the hypothesis, because the parameter estimate for the effect of interaction with customers on delegation is positive and significant ( $t$-value of 4.87). Moreover, we find evidence supporting both Hypothesis 3 ("The more the focal firm delegates responsibility, the more it will use knowledge incentives") and Hypothesis 4 ("The more the focal firm delegates responsibility, the more communication will take place inside it"): delegation significantly and positively impacts on both knowledge incentives and internal communication (with $t$-values of 6.01 and 5.44, respectively). It should be noted that in terms of the coefficient estimate (0.71), the effect of delegation on knowledge incentives is the strongest relationship in the model. We also find strong support for Hypothesis 5 ("The more the focal firm engages in internal communication, the higher will be its innovation performance"), because the correlation coefficient between these constructs is significant at the $1 \%$ level ( $t$-value of 2.58). Similarly, there is support for the hypothesis that the more the focal firm uses knowledge incentives, the higher its innovation performance (Hypothesis 6). In sum, the overall model supports the idea that the link between interaction with customers to innovation performance is indirect: it is mediated through the set of organizational practices we consider here.

In addition, we track the total effect (the sum of direct and indirect effects) of all the constructs on innovation performance. We observe that internal communication and delegation have considerably larger effects on innovation performance ( 0.49 and 0.38 , respectively) than knowledge incentives and interaction with customers ( 0.18 and 0.13 , respectively). This reinforces the point that the effect of interaction with customers on innovation performance is mediated by organizational practices and that firms will only achieve the full potential of their

Figure 2 Estimated Path Model

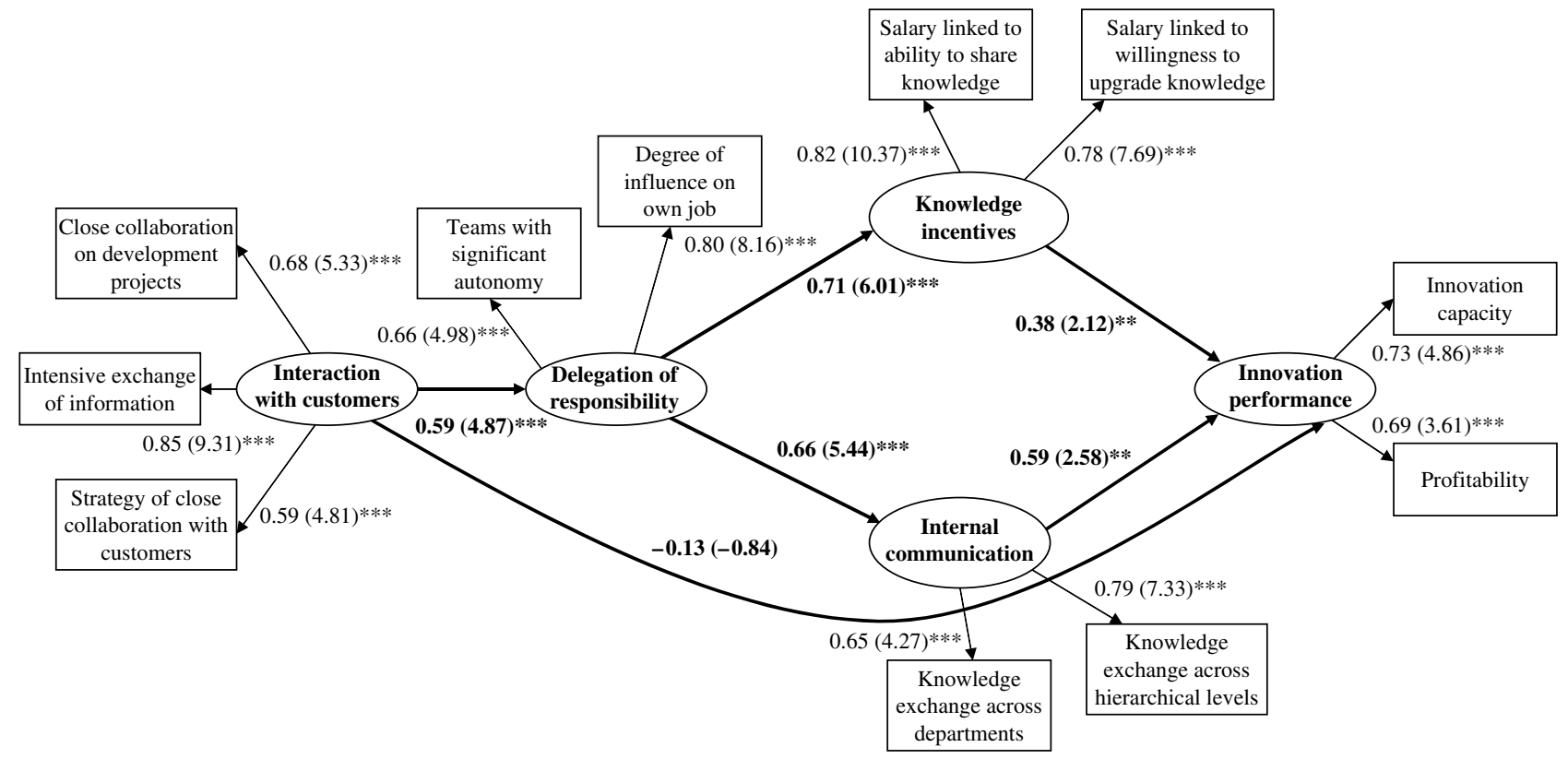

Notes. $t$-Values are given in parentheses. Numbers in bold pertain to the structural model.

${ }^{*}$ Significant at $5 \% \mathrm{~m}^{* *}$ significant at $1 \%$, and ${ }^{* * *}$ significant at $0.1 \%$; two-tailed $t$-test. 
interaction with customers if these organizational practices are in place.

\section{Robustness Checks}

Degree of Mediation. Table 4 presents the GFI for a number of alternative models, allowing for different levels of mediation. Model 3 includes no mediation, only a direct link between interaction with customers and innovation performance. Model 4 includes partial mediation of delegation of responsibility, which has both direct and indirect links to innovation performance. In Model 5, the links between interaction with customers and delegation of responsibility to innovation performance are fully mediated by knowledge incentives and internal communication. With the exception of the insignificant link (in Figure 2) from interaction with customers to innovation performance, Model 5 is identical to our theoretical model. Model 3 with no mediation is clearly a poor representation of the data with $\chi_{(40)}^{2}=160.6(p<0.001)$ and an RMSEA of 0.14 , which suggests that there is no direct link between interaction with customers and innovation performance. Both Model 4 with partial mediation and Model 5 with full mediation fit the data very well, with $\chi_{(37)}^{2}=36.6$ and $\chi_{(39)}^{2}=37.1$, respectively. Adding to Model 5 the extra link between delegation of responsibility and innovation performance in Model 4 renders the new link insignificant, whereas the other links retain their signs. However, the effect of knowledge incentives on innovation performance becomes weaker and insignificant, whereas all other previously significant links retain their significance. Yet the measures of parsimonious GFI and parsimonious NFI are slightly better for Model 5 ( 0.68 and 0.64, respectively) than for Model 4 (0.65 and 0.61, respectively), suggesting that the additional link in Model 4 compared with Model 5 does not improve the model fit. Adding another arrow in Model 5 from knowledge incentives to internal communication does not affect the other results of the model in any important way (and the added effect becomes insignificant). In sum, inclusion of the additional links reveals that our empirical model has a high degree of robustness to alternative specifications.

The overall conclusion based on the test of alternative models is that the relation between interaction with customers and innovation performance is clearly not direct but is fully mediated by the organizational variables included in the model, so firms need to apply organizational variables to benefit from interaction with customers.

Alternative Explanations. To test whether our results could be driven by alternative explanations, we carry out a number robustness checks. These alternative explanations include the fact that some firms in our sample are more knowledge intensive than others, that they are of unequal size, and that they come from different industries. Also, it could be that a firm pursuing a more diversified product strategy needs both more customer interaction and a higher level of delegation. First, we conducted a group analysis for the two groups of firms: ${ }^{5}$ (i) firms with a high proportion of staff employed in R\&D and (ii) firms with a low proportion of employees in R\&D. Overall, the model holds for both groups separately (although some significance is inevitably lost in each case). This suggests that the results are not driven by differences in knowledge intensity. Similarly, we conducted a group analysis for the group of the largest and the group of the smallest firms in our sample. Again, we found that the model, by and large, is confirmed for each of the two groups. As an additional robustness check, we experimented by introducing industry-level $\mathrm{R} \& \mathrm{D}$ (for 29 industries, the highest number for which we had official R\&D statistics). Once more, in the group analysis we found that the results of the model do not differ significantly between firms operating in high- and low-intensive $\mathrm{R} \& \mathrm{D}$ industries. In addition to the group analysis, we carried out four single-equation regressions, all including a set of control variables to test the six relations that we hypothesized in this paper. ${ }^{6}$ Our controls include variables reflecting whether the level of education in the firm was perceived to be higher than in competing firms, the proportion of employees working in $\mathrm{R} \& \mathrm{D}$, whether the firm has foreign ownership, two measures of the degree of product diversification within the firm, industry-level R\&D intensity (29 industries), and 19 industry dummies. The results correspond to the findings from the LISREL analysis: the relation hypothesized in $\mathrm{H} 1$ is insignificant, but all other hypothesized relations are at least significant at the two-sided 5\% level. Another possible concern is whether there is reverse causality between internal communication and innovation. It would be particularly worrying if a firm relying on excellence in operations (or something similar) for differentiation rather than on innovation were in less need of internal communication than a firm trying to differentiate itself via innovation. To address this concern, we ran an extra set of regressions with internal communication determined by the proportion of employees working in $R \& D$ and the variable reflecting level of education in the firm as predictors (to net out firm's innovation aspiration in its internal communication). In the innovation performance equation, we inserted predicted values of internal communication in lieu of the original values. Internal communication remains significant at the $1 \%$ level.

\section{Concluding Discussion}

Since Burns and Stalker's (1961) contribution, identification of intraorganizational antecedents to innovationsuch as organizational structure, human resource management, and other organizational practices-has been a 
central theme in research in organization studies, technology management, and strategic management (e.g., Damanpour 1991, Dougherty 2001, Dougherty and Hardy 1996, Laursen and Foss 2003, Mendelson and Pillai 1999). Most of this research focuses on how the firm can best leverage the knowledge that it already controls in-house for the purposes of innovation. However, it does not address how the firm's organizational practices can positively influence the sourcing of knowledge from external parties, such as users and customers, and its subsequent exploitation for innovation. ${ }^{7}$

The contribution of the present study is to develop a model that highlights the role of certain organizational practices as mediators between firms' interactions with customers and their innovation performance. Specifically, the model highlights the importance of new organizational practices for successful customer innovation from the point of view of established innovating firms. In general, we find empirical support for our model: the effect of interaction with customers on innovation performance is mediated by new organizational practices, and firms can only gain the full potential of their interaction with customers if these organizational practices are in place.

\section{Contribution to Theory}

A prevalent theme in the strategic management and innovation literatures is that firms increasingly need to rely on external knowledge sources to gain and sustain competitive advantage (e.g., Chesbrough 2003, Dyer and Singh 1998, Teece 2000). The purpose of the present work is to enrich our understanding of the role of new organizational practices in the context of absorbing and leveraging customer knowledge that could improve innovation performance. The literature on new organizational practices shows that these practices matter for organizational performance, such as productivity and profitability (e.g., Ichniowski et al. 1997, Mendelson and Pillai 1999). Our reasoning and results strongly support the notion that such organizational practices also influence how external knowledge that initially resided with customers is exploited and built on to produce innovations. The drivers of this process include organizational practices that impact on individual incentives to absorb knowledge from outside the firm and share this knowledge inside the firm, and to improve the capabilities of individuals to absorb and share outside knowledge.

From a somewhat different perspective, the present work can be seen as contributing to the literature on user innovation, which looks at how established firms leverage users' knowledge in the innovation process (Urban and von Hippel 1988, von Hippel 1986). This paper also adds to the open innovation literature to the extent that this literature considers customers to be one of several external sources of innovation (Chesbrough 2003, Fey and Birkinshaw 2005, Laursen and Salter 2006).
These bodies of work tend to use relations between users/customers (and other external sources of innovation) and firms as their unit of analysis, leaving aside the issue of how organizational factors may leverage user knowledge for innovation. By revealing firms in terms of their innovation context and involvement with customers, we add some of organizational components to the user innovation literature.

\section{Limitations and Future Work}

This paper has a number of limitations. Despite the fact that the top management's view is very likely to be well informed, we cannot rule out differences in perception within the organization regarding variables such as delegation and communication. For this reason, a research design that involves multiple respondents could have advantages over the design used in this paper. The focus of this paper is on customer knowledge and how it is leveraged by organizational practices in innovative activity. However, customers are not the only source of external knowledge that influences a producer firm's ability to innovate. Chesbrough (2003) maintains that innovative firms increasingly change their sourcing of new knowledge, adopting an "open innovation" model that implies the use of a wide range of external actors and sources to help them achieve and sustain innovation. The notion of "distributed innovation" (von Hippel 1988) suggests that external knowledge can be obtained from several external sources. Moreover, Baum et al. (2000) show that within biotechnology, innovators rarely innovate alone, whereas Laursen and Salter (2006) demonstrate that a firm's ability to product innovate is strongly influenced by the openness of the firm's external search strategy in terms of the number of external sources of knowledge applied by the firm. Future research should be expanded to deal with the appropriate organizational responses to a much wider range of external knowledge inputs. In this paper, the empirical focus was on the Danish context. Although we believe that our theory will hold in other empirical contexts, future research could examine the generalizability of this work by using data from other geographical contexts.

Future work could also go beyond an emphasis on formal organization. The literature on organization as an antecedent to knowledge sharing and acquisition mainly investigates either formal organization (the present paper, Jansen et al. 2005) or informal organization (see, e.g., Hansen 2002, Tsai 2001). However, there are reasons to expect that informal and formal organization may interact in terms of their impact on knowledge sharing and acquisition. For example, it is plausible to hypothesize that (formal) incentives for knowledge sharing will complement (informal) network ties with respect to the impact on knowledge sharing. Future research should consider such interaction effects in greater detail. 
Future research could also examine individual behaviors more explicitly. Individual action and interaction are the microfoundation for understanding exactly how organizational practices leverage customer knowledge to produce innovation. Thus, organizational practices impact on the incentives and channels of communication available to individuals. Moreover, individuals differ in several respects. For instance, the research presented in this paper can be seen as concerning organizational antecedents to boundary-spanning knowledge search (Rosenkopf and Nerkar 2001). Boundary-spanning individuals need incentives and decision rights to engage in such activities, as well as the possibility to communicate easily with the home organization. The research methodology in this paper is, however, too "reduced form" to capture explicitly these individual-level mediating and moderating effects between customer knowledge and innovation. Understanding this issue is crucial because the choice and design of organizational practices to exploit and build on knowledge for innovation depend on how these practices impact on individual motivation and knowledge, and therefore on individual knowledge seeking and sharing behaviors (Abell et al. 2008).

\section{Acknowledgments}

The authors gratefully acknowledge comments from Gautam Ahuja, Erkko Autio, Erin Anderson, William Baumol, Fabrice Galia, Oliver Gottschalg, Peter G. Klein, Lars Bo Jeppesen, Eric von Hippel, Bruce Kogut, Ram Mudambi, Ammon Salter, Maurizio Zollo, two reviewers of this journal, and audiences at Copenhagen Business School, HEC, INSEAD, the Nordic IB Workshop, the 2006 Strategic Management Society Conference, and the 2007 Academy of Management Conference on earlier versions of this paper. The usual caveats apply.

\section{Endnotes}

${ }^{1}$ The open innovation literature considers customers and users as a (single and important) external source of innovation in addition to such sources as suppliers, competitors, universities, technology consultants, etc.

${ }^{2}$ von Hippel $(1988,1994)$ argues that when users initiate innovations, it is because they have the incentives and knowledge to do so, which established firms often do not have. This might seem to contradict the idea that established organizations collaborate with users to develop new products. However, von Hippel (2005) points out that very often, established firms commercialize end products where a user innovation was of crucial importance in the earliest stages of development. This may be because established firms are more likely to have the necessary complementary assets (Teece 1986).

${ }^{3}$ Henderson and Clark's (1990) study of the semiconductor photolithographic alignment equipment industry demonstrates how firms may have difficulties understanding the architectural dimensions of innovations.

${ }^{4}$ Theoretical arguments (Osterloh and Frey 2000) as well as empirical evidence (Bock et al. 2005) suggest that paying employees for knowledge sharing may lead to a motivation crowding-out effect (Deci 1975, Gagné and Deci 2005): to the extent that such rewards are perceived as being controlling, this may crowd out the intrinsic motivation that some argue is crucial for the efficient functioning of communication and knowledge sharing inside firms (Osterloh and Frey 2000). Although the jury is still out on this issue, psychologybased arguments suggest that rewarding sharing knowledge is an organizational instrument that should be used cautiously.

${ }^{5}$ Group analysis bears some resemblance to including control variables in the regression analysis because it tests for interaction effects of a group variable on the model parameters.

${ }^{6}$ Results are available from the authors upon request.

${ }^{7}$ In contrast, there is a substantial literature on how firms should adapt their organizations in response to the adoption of already existing innovations (see, for instance, Bresnahan et al. 2002, Leonard-Barton and Sinha 1993).

\section{References}

Abell, P., T. Felin, N. Foss. 2008. Building micro-foundations for the routines, capabilities, and performance links. Managerial Decision Econom. 29(6) 489-502.

Allen, T. J. 1977. Managing the Flow of Technology. MIT Press, Cambridge, MA.

Allen, T. J., S. I. Cohen. 1969. Information flow in research and development laboratories. Admin. Sci. Quart. 14(1) 12-19.

Aoki, M. 1986. Horizontal vs. vertical information structures of the firm. Amer. Econom. Rev. 76(5) 971-983.

Baldwin, C. Y., K. B. Clark. 2000. Design Rules: The Power of Modularity, Vol. 1. MIT Press, Cambridge, MA.

Banbury, C. M., W. Mitchell. 1995. The effect of introducing important incremental innovation on market share and business survival. Strategic Management J. 16(S1) 161-182.

Baum, J. A. C., T. Calabrese, B. S. Silverman. 2000. Don't go it alone: Alliance network composition and startups' performance in Canadian biotechnology. Strategic Management J. 21(3) 267-294.

Blundell, R., R. Griffiths, J. V. Reenen. 1999. Market share, market value and innovation in a panel of British manufacturing firms. Rev. Econom. Stud. 66(3) 529-554.

Bock, G.-W., R. W. Zmud, Y.-G. Kim, J.-N. Lee. 2005. Behavioral intention formation in knowledge sharing: Examining the roles of extrinsic motivators, social-psychological forces, and organizational climate. MIS Quart. 29(1) 87-11.

Bollen, K. A. 1989. Structural Equations with Latent Variables. John Wiley \& Sons, New York.

Bresnahan, T. F., E. Brynjolfsson, L. M. Hitt. 2002. Information technology, workplace organization, and the demand for skilled labor: Firm-level evidence. Quart. J. Econom. 117(1) 339-376.

Brynjolfsson, E. 1994. Information assets, technology and organization. Management Sci. 40(12) 1645-1662.

Burnkrant, R. E., T. J. Page Jr. 1982. An examination of the convergent, discriminant, and predictive validity of Fishbein's behavioral intention model. J. Marketing Res. 19(4) 550-561.

Burns, T., G. M. Stalker. 1961. The Management of Innovation. Tavistock, London.

Burton, R. M., B. Obel. 1998. Strategic Organizational Diagnosis and Design. Kluwer, Dordrecht, The Netherlands.

Campbell, D. T., D. W. Fiske. 1959. Convergent and discriminant validation by the multitrait-multimethod matrix. Psych. Bull. 56(2) 81-105. 
Capelli, P., D. Neumark. 2001. Do "high-performance" work practices improve establishment-level outcomes? Indust. Labor Relations Rev. 54(4) 737-775.

Cefis, E., O. Marsili. 2005. A matter of life and death: Innovation and firm survival. Indust. Corporate Change 14(6) 1167-1192.

Chesbrough, H. 2003. Open Innovation. Harvard University Press, Cambridge, MA.

Child, J., R. G. McGrath. 2001. Organizations unfettered: Organizational form in an information-intensive economy. Acad. Management J. 44(6) 1135-1148.

Cohen, W. M., D. A. Levinthal. 1990. Absorptive capacity: A new perspective on learning and innovation. Admin. Sci. Quart. 35(1) $128-152$.

Colombo, M. G., M. Delmastro. 2002. The determinants of organizational change and structural inertia: Technological and organizational factors. J. Econom. Management Strategy 11(4) 595-635.

Czarnitzki, D., K. Kraft. 2004. Innovation indicators and corporate credit ratings: Evidence from German firms. Econom. Lett. 82(3) 377-384.

Damanpour, F. 1991. Organizational innovation: A meta-analysis of effects of determinants and moderators. Acad. Management $J$. 34(3) 555-590.

Datta, D. K., J. P. Guthrie, P. M. Wright. 2005. Human resource management and labor productivity: Does industry matter? Acad. Management J. 48(1) 135-145.

Deci, E. 1975. Intrinsic Motivation. Plenum Press, New York.

Desouza, K. C., Y. Awazu, S. Jha, C. Dombrowski, S. Papagari, P. Baloh, J. Y. Kim. 2008. Customer-driven innovation: To be a marketplace leader, let your customers drive. Res.-Tech. Management 51(3) 35-44.

Dierickx, I., K. Cool. 1989. Asset stock accumulation and sustainability of competitive advantage. Management Sci. 35(12) 1504-1511.

Dougherty, D. 2001. Reimagining the differentiation and integration of work for sustained product innovation. Organ. Sci. 12(5) $612-631$.

Dougherty, D., C. Hardy. 1996. Sustained product innovation in large, mature organizations: Overcoming innovation-to-organization problems. Acad. Management J. 39(5) 1120-1153.

Dyer, J. H., K. Nobeoka. 2000. Creating and managing a highperformance knowledge-sharing network: The Toyota case. Strategic Management J. 21(3) 345-367.

Dyer, J. H., H. Singh. 1998. The relational view: Cooperative strategy and sources of inter-organizational competitive advantage. Acad. Management Rev. 23(4) 660-679.

Ennen, E., A. Richter. 2010. The whole is more than the sum of its parts: Or is it? A review of the empirical literature on complementarities in organization. J. Management 36(1) 207-233.

Fey, C. F., J. Birkinshaw. 2005. External sources of knowledge, governance mode, and R\&D performance. J. Management 31(4) $597-621$.

Fletcher, T. D., L. M. Germano, K. A. Selgrade. 2006. On the use of partial covariances in structural equation modeling. Paper, Twenty-first Annual Conference of the Society for Industrial and Organizational Psychology, Dallas. http://www.umsl.edu/ $\sim$ fletchert/papers/partialcov.pdf.

Fornell, C., D. F. Larcker. 1981. Evaluating structural equation models with unobservable variables and measurement error. J. Marketing Res. 18(1) 39-50.
Foss, N. J. 2003. Selective intervention and internal hybrids: Interpreting and learning from the rise and decline of the Oticon spaghetti organization. Organ. Sci. 14(3) 331-349.

Freeman, C. 1968. Chemical process plant: Innovation and the world market. National Inst. Econom. Rev. 45(August) 29-51.

Gagné, M., E. L. Deci. 2005. Self-determination theory and work motivation. J. Organ. Behav. 26(4) 331-362.

Galbraith, J. R. 1974. Organization design: An information processing view. Interfaces 4(3) 28-36.

Gardiner, J. P., R. Rothwell. 1985. Tough customers: Good designs. Design Stud. 6(1) 7-17.

Gassmann, O. 2006. Opening up the innovation process: Towards an agenda. $R \& D$ Management 36(3) 223-228.

Gerbing, D. W., J. C. Anderson. 1988. An updated paradigm for scale development incorporating unidimensionality and its assessment. J. Marketing Res. 25(2) 186-192.

Geroski, P., S. Machin, J. van Reenen. 1993. The profitability of innovating firms. RAND J. Econom. 24(2) 198-211.

Grinstein, A. 2008. The effect of market orientation and its components on innovation consequences: A meta-analysis. J. Acad. Marketing Sci. 36(2) 166-173.

Guthrie, J. P. 2001. High-involvement work practices, turnover, and productivity: Evidence from New Zealand. Acad. Management J. 44(1) 180-190.

Haefliger, S., G. von Krogh, S. Spaeth. 2008. Code reuse in open source software. Management Sci. 54(1) 180-193.

Hair, J. F., R. E. Anderson, R. L. Tatham, W. C. Black. 1995. Multivariate Data Analysis with Readings, 4th ed. Prentice-Hall, Englewood Cliffs, NJ.

Hall, B. H. 2000. Innovation and market value. R. Barro, G. Mason, M. O'Mahony, eds. Productivity, Innovation and Economic Performance. Cambridge University Press, Cambridge, UK, 177-198.

Hamilton, B. H., J. A. Nickerson, H. Owan. 2003. Team incentives and worker heterogeneity: An empirical analysis of the impact of teams on productivity and participation. J. Political Econom. $111(3)$ 465-497.

Han, J. K., N. Kim, R. K. Srivastava. 1998. Market orientation and organizational performance: Is innovation a missing link? J. Marketing 62(4) 30-45.

Hansen, M. T. 1999. The search-transfer problem: The role of weak ties in sharing knowledge across organizational subunits. Admin. Sci. Quart. 44(1) 82-111.

Hansen, M. T. 2002. Knowledge networks: Explaining effective knowledge sharing in multiunit companies. Organ. Sci. 13(3) 232-248.

Henderson, R., K. B. Clark. 1990. Architectural innovation: The reconfiguration of existing product technologies and the failure of established firms. Admin. Sci. Quart. 35(1) 9-30.

Henderson, R., I. Cockburn. 1994. Measuring competence? Exploring firm effects in pharmaceutical research. Strategic Management J. 15(S1) 63-84.

Henkel, J., E. von Hippel. 2005. Welfare implications of user innovation. J. Tech. Transfer 30(1-2) 73-87.

Holmström, B., J. Roberts. 1998. The boundaries of the firm revisited. J. Econom. Perspect. 12(4) 73-94.

Hurley, R. F., G. T. M. Hult. 1998. Innovation, market orientation, and organizational learning: An integration and empirical examination. J. Marketing 62(3) 42-54. 
Huselid, M. A. 1995. The impact of human resource management practices on turnover, productivity, and corporate financial performance. Acad. Management J. 38(3) 635-672.

Ichniowski, C., K. Shaw. 1999. The effects of human resource management systems on economic performance: An international comparison of U.S. and Japanese plants. Management Sci. 45(5) 704-721.

Ichniowski, C., K. Shaw, G. Prennushi. 1997. The effects of human resource management practices on productivity: A study of steel finishing lines. Amer. Econom. Rev. 87(3) 291-313.

Jaccard, J. J., C. K. Wan. 1996. LISREL Approaches to Interaction Effects in Multiple Regression. Sage, Thousand Oaks, CA.

Jansen, J. J. P., F. A. J. van den Bosch, H. W. Volberda. 2005. Managing potential and realized absorptive capacity: How do organizational antecedents matter? Acad. Management J. 48(6) 999-1015.

Jensen, M. C., W. H. Meckling. 1992. Specific and general knowledge and organizational structure. L. Werin, H. Wijkander, eds. Contract Economics. Blackwell, Oxford, UK, 251-274.

Jöreskog, K.-G., D. Sörbom. 1993. LISREL 8: Structural Equation Modelling with the SIMPLIS Command Language. Scientific Software International, Chicago.

Kogut, B., U. Zander. 1992. Knowledge of the firm, combinative capabilities, and the replication of technology. Organ. Sci. 3(3) 383-397.

Laudon, K. C., J. P. Laudon. 2002. Management Information Systems: Managing the Digital Firm, 7th ed. Prentice Hall, Englewood Cliffs, NJ.

Laursen, K., N. Foss. 2003. New human resource management practices, complementarities, and the impact on innovation performance. Cambridge J. Econom. 27(2) 243-263.

Laursen, K., A. J. Salter. 2006. Open for innovation: The role of openness in explaining innovative performance among UK manufacturing firms. Strategic Management J. 27(2) 131-150.

Lawler, E. E. I., S. A. Mohrman, G. E. Ledford Jr. 1998. Strategies for High Performance Organizations: Employee Involvement, TQM, and Reengineering Programs in Fortune 1000 Corporations. Jossey-Bass, San Francisco.

Leonard-Barton, D., D. K. Sinha. 1993. Developer-user interaction and user satisfaction in internal technology transfer. Acad. Management J. 36(5) 1125-1139.

Lichtenthaler, U. 2008. Open innovation in practice: An analysis of strategic approaches to technology transactions. IEEE Trans. Engrg. Management 55(1) 148-157.

Lilien, G. L., P. D. Morrison, K. Searls, M. Sonnack, E. von Hippel. 2002. Performance assessment of the lead user idea-generation process for new product development. Management Sci. 48(8) $1042-1059$.

Lindell, M. K., D. J. Whitney. 2001. Accounting for common method variance in cross-sectional research designs. J. Appl. Psych. 86(1) 114-121.

Linder, S. B. 1961. An Essay on Trade and Transformation. Almquist and Wiksell, Stockholm.

Love, J. H., S. Roper. 2009. Organizing innovation: Complementarities between cross-functional teams. Technovation 29(3) 192-203.

Lukas, B. A., O. C. Ferrell. 2000. The effect of market orientation on product innovation. J. Acad. Marketing Sci. 28(2) 239-247.
Lynex, A., P. J. Layzell. 1998. Organisational considerations for software reuse. Ann. Software Engrg. 5 105-124.

Matusik, S. 2002. Managing public and private firm knowledge within the context of flexible firm boundaries. C. W. Choo, N. Bontis, eds. Strategic Management of Intellectual Capital and Organizational Knowledge. Oxford University Press, Oxford, UK, 605-620.

McEvily, S. K., B. Chakravarthy. 2002. The persistence of knowledgebased advantage: An empirical test for product performance and technological knowledge. Strategic Management J. 23(4) 285-305.

Mendelson, H. 2000. Organizational architecture and success in the information technology industry. Management Sci. 46(4) 513-529.

Mendelson, H., R. R. Pillai. 1999. Information age organizations, dynamics, and performance. J. Econom. Behav. Organ. 38(3) 253-281.

Narver, J. C., S. F. Slater. 1990. The effect of a market orientation on business profitability. J. Marketing 54(4) 20-35.

Narver, J. C., S. F. Slater, D. L. MacLachlan. 2004. Responsive and proactive market orientation and new-product success. J. Product Innovation Management 21(5) 334-347.

Neale, M. R., D. R. Corkindale. 1998. Co-developing products: Involving customers earlier and more deeply. Long Range Planning 31(3) 418-425.

Nelson, R. R., S. G. Winter. 1982. An Evolutionary Theory of Economic Change. Harvard University Press, Cambridge, MA.

Nickerson, J. A., T. R. Zenger. 2004. A knowledge-based theory of the firm: The problem-solving perspective. Organ. Sci. 15(6) 617-632.

Osterloh, M., B. S. Frey. 2000. Motivation, knowledge transfer, and organizational form. Organ. Sci. 11(3) 538-550.

Pavitt, K. 1984. Sectoral patterns of technical change: Towards a taxonomy and a theory. Res. Policy 13(6) 343-373.

Podsakoff, P. M., S. B. MacKenzie, J.-Y. Lee, N. P. Podsakoff. 2003. Common method biases in behavioral research: A critical review of the literature and recommended remedies. J. Appl. Psych. 88(5) 879-903.

Porter, L. W., E. E. Lawler. 1968. Managerial Attitudes and Performance. Dorsey Press, Homewood, IL.

Roberts, J. 2007. The Modern Firm: Organizational Design for Performance and Growth. Oxford University Press, Oxford, UK.

Rosenberg, N. 1982. Learning by using. Inside the Black Box: Technology and Economics. Cambridge University Press, Cambridge, UK, 120-140.

Rosenkopf, L., A. Nerkar. 2001. Beyond local research: Boundaryspanning, exploration, and impact in the optical disk industry. Strategic Management J. 22(4) 287-306.

Rothwell, R., C. Freeman, P. Jervis, A. Robertson, J. Townsend. 1974. SAPPHO updated-Project SAPPHO phase II. Res. Policy 3(3) 258-291.

Salancik, G. R., J. Pfeffer. 1977. An examination of need-satisfaction models of job attitudes. Admin. Sci. Quart. 22(3) 427-456.

Schumpeter, J. A. 1934. The Theory of Economic Development: An Inquiry into Profits, Capital, Credit, Interest and the Business Cycle. Oxford University Press, London. [Originally published in 1912 as Theorie der wirtschaftlichen Entwicklung. Duncker \& Humblot, Leipzig, Germany.] 
Slater, S. F., J. C. Narver. 1994. Does competitive environment moderate market orientation-performance relationship? J. Marketing 58(1) $46-55$

Szulanski, G. 1996. Exploring internal stickiness: Impediments to the transfer of best practice. Strategic Management J. 17(Winter special issue) $27-43$.

Teece, D. J. 1986. Profiting from technological innovation: Implications for integration collaboration, licensing and public policy. Res. Policy 15(6) 285-305.

Teece, D. J. 2000. Managing Intellectual Capital: Organizational, Strategic, and Policy Dimensions. Oxford University Press, Oxford, UK.

Teece, D. J., G. Pisano, A. Shuen. 1997. Dynamic capabilities and strategic management. Strategic Management J. 18(7) 509-533.

Tsai, W. 2001. Knowledge transfer in intra-organizational networks: Effects of network position and absorptive capacity on business unit innovation and performance. Acad. Management J. 44(5) 996-1004.

Tsai, W., S. Ghoshal. 1998. Social capital and value creation: The role of intrafirm networks. Acad. Management J. 41(4) 464-476.

Tushman, M., D. Nadler. 1978. Information processing as an integrating concept in organizational design. Acad. Management Rev 3(3) 613-624.

Tushman, M. L., R. Katz. 1980. External communication and project performance-An investigation into the role of gatekeepers. Management Sci. 26(11) 1071-1085.

Urban, G. L., E. von Hippel. 1988. Lead user analyses for the development of new industrial products. Management Sci. 34(5) 569-582.

Volberda, H. W., N. J. Foss, M. A. Lyles. 2010. Absorbing the notion of absorptive capacity: How to realize its potential in the organization field. Organ. Sci. 21(4) 931-951.

von Hippel, E. 1976. The dominant role of users in scientific instrument innovation process. Res. Policy 5(3) 212-239.

von Hippel, E. 1986. Lead users: A source of novel product concepts. Management Sci. 32(7) 791-805.

von Hippel, E. 1988. The Sources of Innovation. Oxford University Press, New York. von Hippel, E. 1994. "Sticky information" and the locus of problem solving: Implications for innovation. Management Sci. 40(4) 429-439.

von Hippel, E. 1998. Economics of product development by users: The impact of "sticky" local information. Management Sci. 44(5) 629-644.

von Hippel, E. 2005. Democratizing Innovation. MIT Press, Cambridge, MA.

Zenger, T. R., W. S. Hesterly. 1997. The disaggregation of corporations: Selective intervention, high-powered incentives and molecular units. Organ. Sci. 8(3) 209-222.

Zott, C. 2003. Dynamic capabilities and the emergence of intraindustry differential firm performance: Insights from a simulation study. Strategic Management J. 24(2) 97-125.

Nicolai J. Foss is a professor at the Copenhagen Business School's Center for Strategic Management and Globalization and a professor at the Norwegian School of Economics and Business Administration, and the Svenska Handelsbanken Visiting Professor at Lund University. He has published more than 120 papers in scholarly journals and has written and edited several books on strategic management, entrepreneurship, organizational theory, and the methodology of the social sciences.

Keld Laursen is a professor of the economics and management of innovation at Copenhagen Business School. He earned his doctorate in international economics from Aalborg University. His current research focuses on open and distributed innovation processes and on organizational practices and innovation outcomes.

Torben Pedersen is a professor at the Copenhagen Business School's Center for Strategic Management and Globalization. He has published over 70 articles and books on the managerial and strategic aspects of globalization. His research has appeared in journals such as the Strategic Management Journal, Journal of International Business Studies, Journal of Management Studies, and Journal of Corporate Finance. He is coeditor of the Global Strategy Journal and serves on numerous editorial boards. 